\title{
Occurrence of phosphatic corrosion products on bronze swords of the Warring States period buried at Lijiaba site in Chongqing, China
}

\author{
Xiaopan Fan ${ }^{1^{*}}$ (D) and lan C. Freestone ${ }^{2}$
}

\begin{abstract}
Corrosion products on three bronze swords found in tombs dating from the Warring States period at Lijiaba site, Yunyang county, Chongqing were characterized by Raman and X-ray fluorescence spectroscopies. The major corrosion products were cuprite, malachite, cerussite and cassiterite, along with the copper and lead phosphates, libethenite and pyromorphite. The presence of libethenite and pyromorphite which have been reported infrequently in bronze corrosion products were attributed to the $\mathrm{pH}$, humidity and phosphorus released by the decomposition of the adjacent bodies in the burial environment.
\end{abstract}

Keywords: Bronze sword, Raman spectroscopy, Lijiaba, Libethenite, Pyromorphite, X-ray fluorescence spectroscopy

\begin{abstract}
Introduction
The study of the corrosion products on archaeological bronzes is particularly important for a better understanding of the condition, possible conservation strategy and restoration strategy of bronze artifacts [1-3]. A large variety of analytical techniques including optical microscopy (OM), X-ray diffraction (XRD), X-ray fluorescence spectroscopy (XRF), scanning electron microscopy with energy dispersive X-ray spectroscopy (SEM-EDX), Fourier transform infrared spectroscopy (FTIR), X-ray photoelectron spectroscopy (XPS), Raman spectroscopy, glow discharge optical emission spectrometry (GDOES), time-of-flight secondary ion mass spectrometry (TOFSIMS), synchrotron radiation FTIR (SR-FTIR) and synchrotron radiation XRD (SR-XRD), and X-ray absorption near edge structure (XANES) spectroscopy have been used to investigate structures and compositions of the corrosion products in recent years [4-9]. It is well known that the character of the corrosion products of bronze
\end{abstract}

\footnotetext{
*Correspondence: fxiaopan@163.com

${ }^{1}$ Chongqing China Three Gorges Museum, 236 Renmin Road,

Chongqing 400015, China

Full list of author information is available at the end of the article
}

artifacts buried in soil depends on multiple factors such as the nature of the alloy, soil composition, porosity, humidity, conductivity, depth and duration of burial [10, 11].

The Lijiaba site $\left(31^{\circ} 6^{\prime} 15^{\prime \prime} \mathrm{N}, 108^{\circ} 41^{\prime} \mathrm{E}\right.$, Fig. 1), located in Qingshu village of Yunyang county in Chongqing (southwest China) and by the Pengxi River (a branch of the Yangtze River), is a well-preserved cultural site. Material remains revealed by archaeological surveys and excavations in 1998 and 1999 suggest this site was occupied from the Shang-Zhou Dynasty to the Six Dynasties (1700 $\mathrm{BC}-600 \mathrm{AD})[12,13]$. Due to the outstanding nature of the finds, it was selected as one of the top ten archaeological discoveries in China in 1998. A large number of tombs belonging to the Eastern Zhou Dynasty (770-221 $\mathrm{BC})$, which comprises the Spring and Autumn period (770-475 BC) and the Warring States period (475221 BC) were excavated. Many bronze weapons were unearthed including swords, spears, pole spears, daggeraxes and fu-axes, a type of assemblage which differs from burial sites of the period in other areas of China where large numbers of sacrificial vessels have been recovered. The bronze weapons at Lijiaba site show decorative motifs which include tigers, aquatic birds, cicadas, arms, 


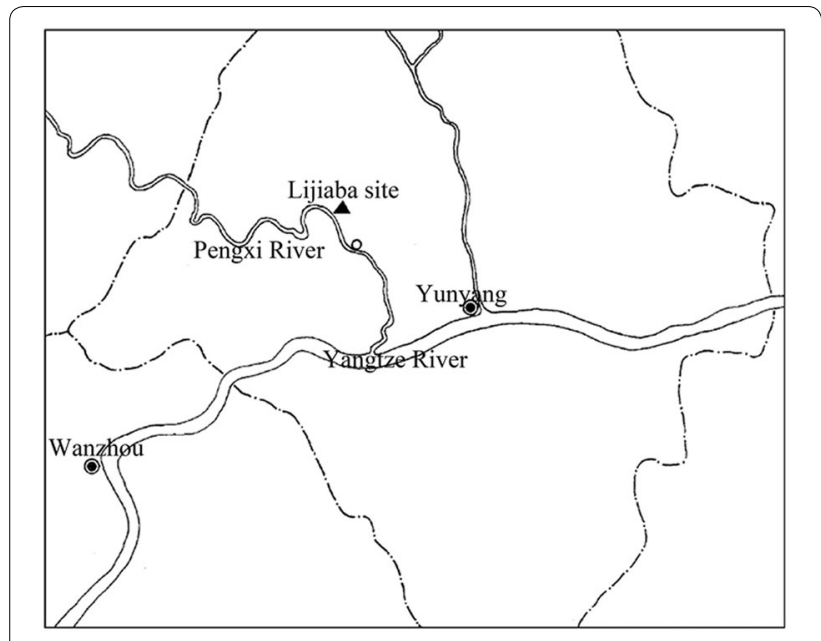

Fig. 1 The location map of Lijiaba site [12]

hearts, cloudscapes and other patterns on swords, spears, dagger-axes, whereas geometrical patterns were found on the axes and large battle-axes. These are the typical characteristics of the $\mathrm{Ba}$, an ethnic group living in the Three Gorges region (Qutang Gorge, Wu Gorge and Xiling Gorge of the Yangtze river) through the Shang Dynasty to the Qin Dynasty.

Recent research has been undertaken on the bronzes unearthed in the Three Gorges region, focusing on the elemental/composition and metallography of the metals, and production technology of the bronze artifacts [14, 15], but very limited research has been carried out on their corrosion products. As part of the program of conservation of the bronzes, their corrosion was investigated.

The bronzes unearthed at Lijiaba were found covered in corrosion, and were stored without any environmental control until 2013. Following this they were moved to a new store with controlled constant temperature and humidity. The characterization of the corrosion products is therefore particularly important for a better understanding of the condition and stability of the bronzes, an understanding of the corrosive environment they experienced in the past, and possible conservation and restoration in future. It will serve as baseline against which any future changes may be identified.

Raman spectroscopy is an ideal technique for the study for the investigation of works of art and their degradation products because it is extremely reliable, sensitive, compound-specific and is non-destructive. Hence it has been used frequently in the analysis of corrosion products on bronze [16-19]. In the present study, Raman spectroscopy supplemented by X-ray fluorescence spectroscopy
Table 1 Samples studied

\begin{tabular}{llll}
\hline Sample number & $\begin{array}{l}\text { Archaeological } \\
\text { number }\end{array}$ & Sample area & Description \\
\hline YLS1-1 & 00YLIIM82:2 & a in Fig. 2A & Brown \\
YLS1-2 & 00YLIIM82:2 & b in Fig. 2A & Green \\
YLS1-3 & 00YLIIM82:2 & c in Fig. 2A & Grey green \\
YLS1-4 & 00YLIIM82:2 & d in Fig. 2A & Green, white \\
YLS2-1 & 98YLIIM10:1 & a in Fig. 2B & Grey green \\
YLS2-2 & 98YLIIM10:1 & b in Fig. 2B & Brown \\
YLS3-1 & $98 Y L I I M 11: 4$ & a in Fig. 2C & Grey green \\
YLS3-2 & $98 Y L I I M 11: 4$ & b in Fig. 2C & Green, red, brown \\
\hline
\end{tabular}

was used to identify the corrosion products grown on three bronze swords excavated at Lijiaba.

\section{Materials and methods}

The swords for analysis were unearthed from different tombs dating to the Warring States period: YLS1 (archaeological excavation number: 00YLIIM82:2) was excavated in 2000, whereas YLS2 (98YLIIM10:1) and YLS3 (98YLIIM11:4) were unearthed in 1998. Corrosion product samples, selected from each of the three swords according to their color and morphology, are listed in Table 1, with the positions on the swords shown in Fig. 2.

A Renishaw inVia Raman microscope system was used to record the Raman spectrum of samples at room temperature. The spectra were recorded from 1300 to $60 \mathrm{~cm}^{-1}$ in static mode with a laser wavelength of $532 \mathrm{~nm}$ and $50 \times$ objective lens. Laser power was chosen for emission at $1 \%$ power, about $0.5 \mathrm{~mW}$. The integration time was $10 \mathrm{~s}$, and the number of collected accumulations was from 1 to 10 depending on the sample. Repeat measurements were carried out on different areas of the samples. All spectra were baseline corrected in the software.

Semi-quantitative elemental analysis was performed on solid corrosion product samples using a Shimadzu XRF-1800 fluorescence spectrometer equipped with a rhodium (Rh) target. The tube voltage was $40 \mathrm{kV}$, and the current was $95 \mathrm{~mA}$. The analysis area measured is $3 \mathrm{~mm}$ in diameter.

Soil samples from the surfaces of the swords were insufficient for analysis, but soils attached to artefacts in the same or nearby burials were available. Soil was removed from the surfaces of bronze artefacts and ground and sieved through 60 mesh. Samples of $0.2 \mathrm{~g}$ were dissolved and diluted with ultra-pure water to $25 \mathrm{ml}$ and placed in an ultrasonic bath for $60 \mathrm{~min}$, then centrifuged for $10 \mathrm{~min}$. The supernatant solution was stored in a refrigerator before ion measurement. The solutions 

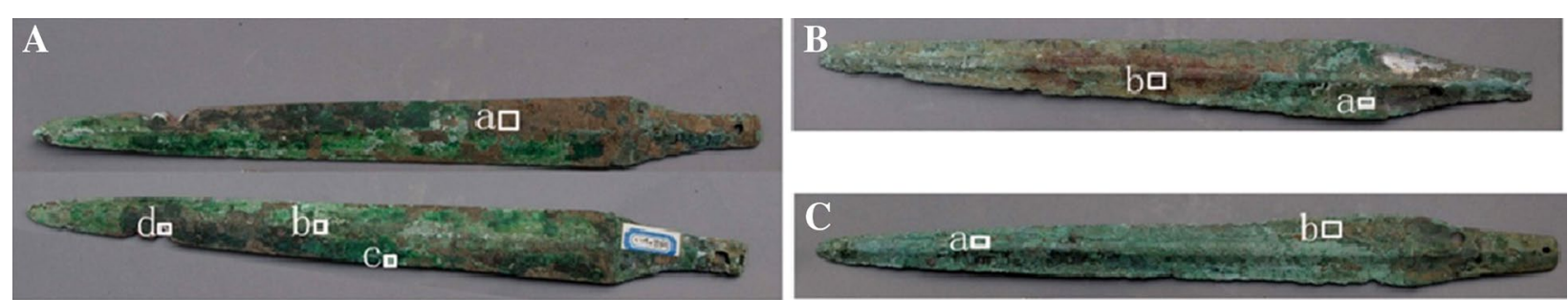

Fig. 2 Bronze swords unearthed at Lijiaba site, showing sampling locations (A 00YLIIM82:2, B 98YLIIM10:1, C 98YLIIM11:4)

were filtered using a filter membrane of $0.45 \mu \mathrm{m}$ and $\mathrm{PO}_{4}^{3-}$ concentrations were measured using a DIONEX AS-DV with AS11-HC, USA [20].

\section{Results}

\section{X-ray fluorescence spectroscopy}

The XRF analyses (Table 2) show that the main elements present in the corrosion products are copper, lead, tin, phosphorus, chlorine, silicon, potassium, aluminum, iron and calcium. Copper, lead and tin are the main elements of bronzes, while silicon, potassium, aluminum and iron are likely to represent soil which was incorporated during burial. It can be concluded from its high content of $\mathrm{Si}$, $\mathrm{Al}, \mathrm{Fe}$ and $\mathrm{K}$ that YLS1-1 represents a mixture of soil and corrosion, whereas the other samples contain relatively low amounts of soil. Phosphorus was detected in every sample, with the highest value measured at 9.9\%. Chlorine was detected in several samples such as YLS2-1, YLS2-2 and YLS3-2 with a content near 1\%.

\section{Raman spectroscopy}

Corrosion products were found to be carbonates, oxides and phosphates of the main alloying metals, $\mathrm{Cu}, \mathrm{Pb}$ and $\mathrm{Sn}$. The phases identified in each sample are listed in Table 3.

(1) Malachite

Malachite $\left(\mathrm{Cu}_{2}\left(\mathrm{CO}_{3}\right)(\mathrm{OH})_{2}\right)$ was the most common corrosion product, detected in six of the eight samples analyzed (Table 3), and present on every sword.

Table 2 Semi-quantitative XRF analysis of samples

\begin{tabular}{|c|c|c|c|c|c|c|c|c|c|c|c|}
\hline Sample number & $\mathrm{Cu}$ & Sn & $\mathrm{Pb}$ & $\mathrm{Si}$ & Al & $\mathrm{Fe}$ & $\mathrm{Ca}$ & $\mathrm{K}$ & $P$ & $\mathrm{Cl}$ & As \\
\hline YLS1-1 & 24.3 & & 12.8 & 31.9 & 6.4 & 8.5 & 5.6 & 6.2 & 2.8 & & \\
\hline YLS1-2 & 71.1 & 1.3 & 3.8 & 4.8 & 0.9 & 0.8 & 6.8 & 0.6 & 9.9 & & \\
\hline YLS1-3 & 66.5 & 25.0 & 2.3 & 1.7 & 0.4 & & 1.1 & & 3.1 & & \\
\hline YLS1-4 & 26.8 & 63.0 & 8.9 & 1.1 & & & & & 0.2 & & \\
\hline YLS2-1 & 15.7 & 61.4 & 18.7 & 1.3 & & & & & 1.3 & 1.1 & 1.58 \\
\hline YLS2-2 & 21.5 & 4.6 & 62.3 & 2.3 & 1.4 & 0.5 & 0.7 & 0.4 & 5.0 & 1.4 & \\
\hline YLS3-1 & 50.9 & 38.2 & 7.7 & 1.3 & 0.3 & & & & 1.8 & & \\
\hline YLS3-2 & 47.3 & 9.1 & 34.9 & 1.5 & & & 1.3 & & 3.7 & 1.3 & \\
\hline
\end{tabular}

Table 3 Corrosion products identified using Raman spectroscopy

\begin{tabular}{lll}
\hline Sample number & Archaeological number & Identified corrosion product \\
\hline YLS1-1 & $00 Y L I I M 82: 2$ & Malachite, cuprite \\
YLS1-2 & $00 Y L I I M 82: 2$ & Libethenite, cuprite \\
YLS1-3 & $00 Y L I I M 82: 2$ & Libethenite, malachite \\
YLS1-4 & $00 Y L I I M 82: 2$ & Cuprite, cassiterite \\
YLS2-1 & $98 Y L I I M 10: 1$ & Pyromorphite, cassiterite, malachite, cuprite \\
YLS2-2 & $98 Y L I I M 10: 1$ & Malachite, cuprite, cassiterite, cerussite, pyromorphite \\
YLS3-1 & $98 Y L I I M 11: 4$ & Malachite, cuprite, libethenite, cassiterite, \\
YLS3-2 & $98 Y L I I M 11: 4$ & Malachite, cerussite, cuprite, pyromorphite \\
\hline
\end{tabular}


The spectrum of sample YLS1-1 (Fig. 3) is typical, where the Raman peaks at 1095, 1055, 751, 720, 599, 566, 535, 511, 432, 355, 271, 219, 181 and $153 \mathrm{~cm}^{-1}$ correspond to the Raman peaks of previously identified archaeological malachite as shown in Table 4 [21].

(2) Cuprite

The well-defined Raman band present at $218 \mathrm{~cm}^{-1}$ in Fig. 3 is characteristic of cuprite (cuprous oxide, $\mathrm{Cu}_{2} \mathrm{O}$ ) [22] and the peaks observed at $629,219,153$, 108 and $79 \mathrm{~cm}^{-1}$ in Fig. 3 are also associated with this mineral $[22,23]$. The presence of cuprite peaks within the malachite spectrum is a common phenomenon in Raman spectroscopy of archaeological malachite, due to the close association of the two phases in copper corrosion processes [21].

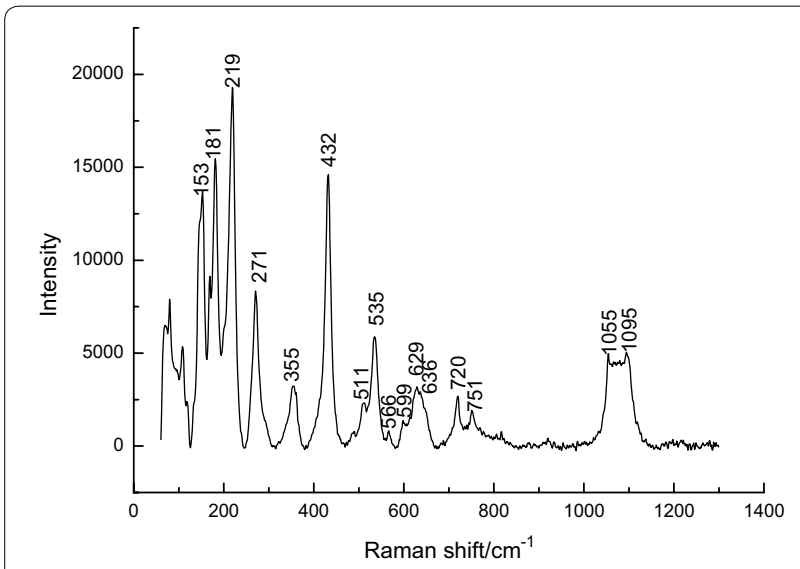

Fig. 3 Raman spectrum of sample YLS1-1 (malachite and cuprite)
(3) Libethenite

The Raman spectrum of YLS1-2 is shown in Fig. 4. According to published data [24, 25], the Raman spectra collected from this and samples YLS1-3 and YLS3-1 strongly suggest the presence of libethenite $\left(\mathrm{Cu}_{2}(\mathrm{OH}) \mathrm{PO}_{4}\right)$ as shown in Table 5. This identification is consistent with the XRF results which show high levels of phosphate in the corrosion products. According to the band assignments previously reported [24-28], the very strong band at $972 \mathrm{~cm}^{-1}$ may be assigned to the $\mathrm{v}_{1}$ symmetric stretching vibration, whereas the $\mathrm{v}_{3}$ antisymmetric stretching is represented by the strong band at $1017 \mathrm{~cm}^{-1}$, with $\mathrm{v}_{2}$ symmetric bending modes occurring at $386 \mathrm{~cm}^{-1}$ and $\mathrm{v}_{4}$ antisymmetric bending vibrations at 625,585 and $556 \mathrm{~cm}^{-1}$. A broad band is observed for libet-

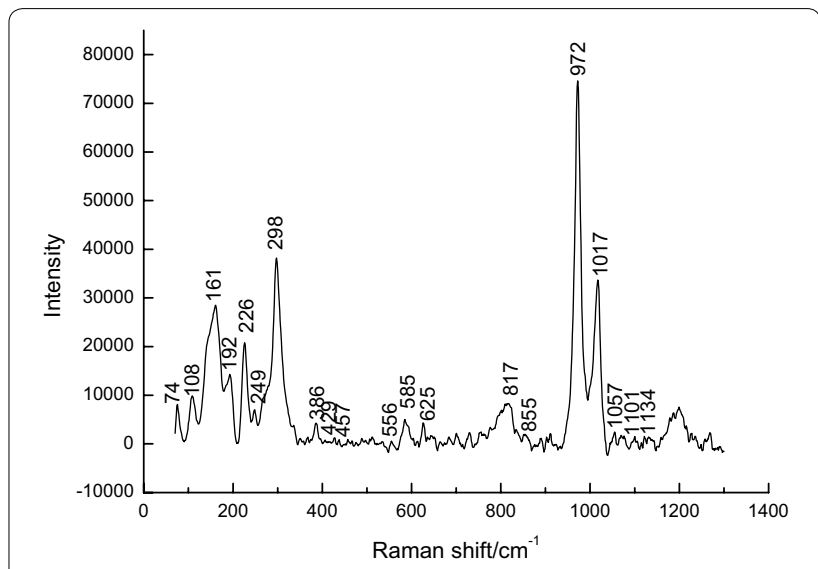

Fig. 4 Raman spectrum of sample YLS1-2 (libethenite)

Table 4 Raman bands of phases identified as malachite $\left(\mathrm{cm}^{-1}\right)$

\begin{tabular}{lllllll}
\hline YLS1-1 & YLS1-3 & YLS2-1 & YLS2-2 & YLS3-1 & YLS3-2 & Archaeological malachite [21] \\
\hline 1095 & 1094 & 1095 & 1097 & 1096 & 1088 & $1093 \pm 10(0-\mathrm{m})$ \\
1055 & 1069 & 1059 & 1054 & 1057 & 1053 & $1061 \pm 7(0-\mathrm{m})$ \\
751 & 752 & 750 & 754 & 750 & 755 & $754 \pm 2(0-\mathrm{m})$ \\
720 & 718 & 718 & 718 & 718 & 717 & $718 \pm 6(0-\mathrm{m})$ \\
599 & 598 & 594 & 600 & 598 & 600 & $599 \pm 2(0-\mathrm{m})$ \\
566 & 567 & 564 & 569 & 563 & 570 & $566 \pm 3(0-\mathrm{m})$ \\
535 & 534 & 534 & 534 & 534 & 535 & $533 \pm 5(0-\mathrm{s})$ \\
511 & 510 & 507 & & 508 & 432 & $431 \pm 4(0-\mathrm{m})$ \\
432 & 431 & 431 & 432 & 431 & 362 & $355 \pm 5(0-\mathrm{m})$ \\
355 & 355 & 352 & 357 & 352 & 268 & $274 \pm 7(0-\mathrm{vs})$ \\
271 & 260 & 269 & 216 & 218 & 218 & $217 \pm 8(\mathrm{~m}-\mathrm{vs})$ \\
219 & 222 & 218 & 180 & 180 & 179 & $179 \pm 7$ (m-vs) \\
181 & 180 & 179 & 153 & 152 & 154 & $153 \pm 4(0-\mathrm{vs})$
\end{tabular}

$\mathrm{m}$, medium; vs, very strong; s, strong; 0 , not detected 
Table 5 Raman bands of phases identified as libethenite $\left(\mathrm{cm}^{-1}\right)$

\begin{tabular}{|c|c|c|c|c|}
\hline \multicolumn{3}{|c|}{ Raman bands of samples } & \multicolumn{2}{|c|}{$\begin{array}{l}\text { Raman peaks of libethenite } \\
\text { in reference }\end{array}$} \\
\hline YLS1-2 & YLS1-3 & YLS3-1 & Frost [24] & Kharbish [25] \\
\hline 1134 & 1135 & 1132 & & 1130 \\
\hline 1101 & 1107 & & & 1102 \\
\hline 1070 & 1069 & 1076 & & 1075 \\
\hline 1057 & 1050 & 1057 & 1050 & 1052 \\
\hline \multirow[t]{2}{*}{1017} & 1017 & 1016 & 1019 & 1022 \\
\hline & & & & 1008 \\
\hline \multirow[t]{2}{*}{972} & 972 & 971 & 975 vs & 979 \\
\hline & & & & 944 \\
\hline 855 & 868 & 861 & 862 & 864 \\
\hline \multirow[t]{2}{*}{817} & 823 & 817 & 815 & 818 \\
\hline & & 651 & 645 & 650 \\
\hline 625 & 625 & 625 & 626 & 625 \\
\hline 585 & 587 & 580 & 582 & 590 \\
\hline 556 & 554 & & 556 & 561 \\
\hline 457 & 451 & & 450 & 461 \\
\hline 429 & 436 & 429 & & 430 \\
\hline 386 & 387 & 386 & 387 & 392 \\
\hline \multirow[t]{2}{*}{367} & & 365 & & 371 \\
\hline & & & & 319 \\
\hline \multirow[t]{2}{*}{298} & 298 & 298 & 298 & 301 \\
\hline & 265 & & 278 & 270 \\
\hline 249 & 247 & 248 & 248 & 250 \\
\hline 226 & 226 & 226 & 226 & 227 \\
\hline 192 & 193 & 192 & & 195 \\
\hline \multirow[t]{2}{*}{161} & 156 & 160 & & 160 \\
\hline & & & & 140 \\
\hline \multirow[t]{2}{*}{108} & 108 & 106 & & 113 \\
\hline & & & & 92 \\
\hline 74 & & 78 & & 74 \\
\hline
\end{tabular}

henite at $817 \mathrm{~cm}^{-1}$. The lattice modes appear at 298 , 249, 226, 192, 161, 108 and $74 \mathrm{~cm}^{-1}$. (The presence of libethenite in sample YLS1-2 was confirmed by $\mathrm{X}$-ray powder diffraction [29]). Libethenite is a secondary copper phosphate mineral commonly found in the oxidized zone of copper ore deposits. It was named in 1823 by August Breithaupt in Lubietová, Slovakia after the German name of that locality, Libethen.

(4) Cassiterite

It is reported that cassiterite $\left(\mathrm{SnO}_{2}\right)$ is characterized by strong band at $635(638) \mathrm{cm}^{-1}$ and weak peaks at 476 and $782(775) \mathrm{cm}^{-1}[23,30,31]$. The peaks at 640 and $475 \mathrm{~cm}^{-1}$ in Fig. 5 are attributed to cassiterite. The Raman results showed that cassiterite

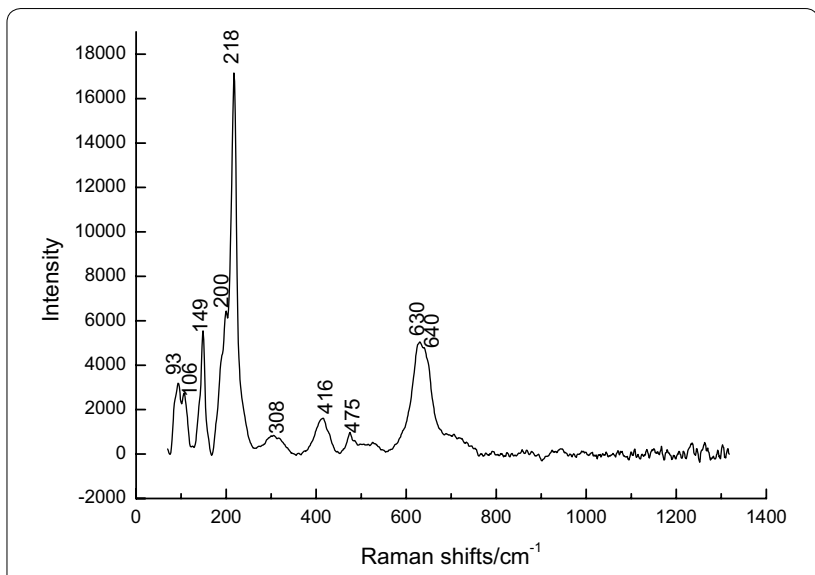

Fig. 5 Raman spectrum of sampleYLS1-4 (cuprite and cassiterite)

is found in samples YLS1-4, YLS2-1, YLS2-2 and YLS3-1 (Table 3).

(5) Cerussite

Raman spectroscopy confirmed the presence of cerussite $\left(\mathrm{PbCO}_{3}\right)$ or hydrocerussite $\left(\mathrm{Pb}_{3}\right.$ $\left.\left(\mathrm{CO}_{3}\right)_{2}(\mathrm{OH})_{2}\right)$ in samples YLS2-2 and YLS3-2 through the identification of the sharp peak at $1052 \mathrm{~cm}^{-1}$ [23].

(6) Pyromorphite

The Raman peaks of YLS2-2 (Fig. 6) located at 945, 919, 411, 392 and $105 \mathrm{~cm}^{-1}$ are ascribable to the lead chlorophosphate, pyromorphite $\left(\mathrm{Pb}_{5}\left(\mathrm{PO}_{4}\right)_{3} \mathrm{Cl}\right)$ [32, 33], whereas the peaks at 1052 and $218 \mathrm{~cm}^{-1}$ are respectively attributed to the presence of cerussite and cuprite [23]. Sample YLS2-1 showed additional peaks at 808 and $770 \mathrm{~cm}^{-1}$ which may reflect the substitution for phosphate in the pyromorphite by arsenic [33, 34] as the XRF analysis of this sample indicated a significant as content (Table 2).

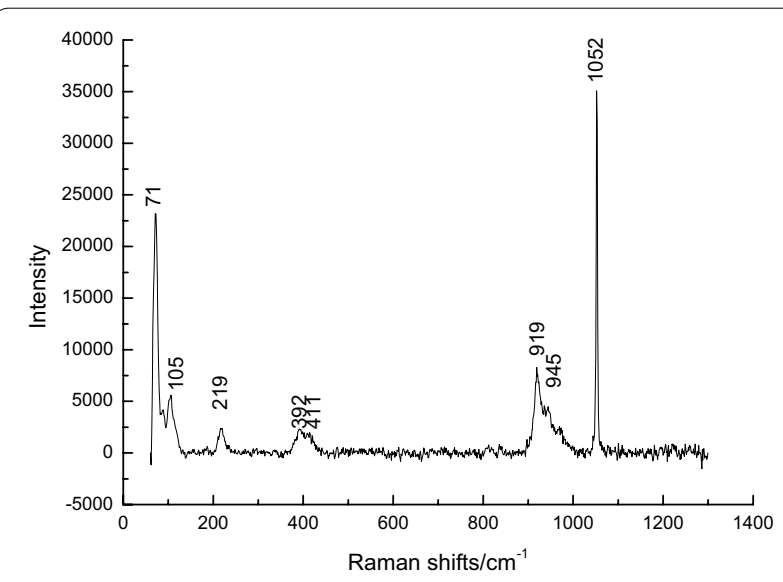

Fig. 6 Raman spectrum of sample YLS2-2 (pyromorphite, cerussite and cuprite) 


\section{Soil analysis}

Soil samples collected from the swords analyzed in this article were not available for IC analysis. However, soil samples from the same or adjacent burials were analyzed. Soil from the surface of a bronze spear (archaeological number 98YLIIM11:6) in the same tomb as sword YLS3 showed significant levels of chloride $(161 \mathrm{mg} / \mathrm{kg})$, phosphate $(646 \mathrm{mg} / \mathrm{kg})$, sulphate $(498 \mathrm{mg} / \mathrm{kg})$ and nitrate (386 mg/kg). The weight of available soil samples on the bronze artifacts from the three tombs (00YLIIM82, 98YLIIM11 and 98YLIIM10) where the swords were unearthed was not sufficient to determine the $\mathrm{pH}$. However, $\mathrm{pH}$ values of two other soil samples from close to bronze artifacts 00YLIIM29:8 and 00YLIIM6:4 in the same site were 6.9 and 7.8 .

\section{Discussion}

Chinese bronze artefacts mainly contain copper, tin and lead and the corrosion products of these metals are to be expected. Malachite, cuprite, cassiterite and cerussite have frequently been reported in bronze corrosion products [2-9]. Malachite and cuprite are common corrosion products of copper alloys after long burial periods in soils [2]. Cuprite forms a red layer in contact with the metal core. In the presence of $\mathrm{H}_{2} \mathrm{O}$ and $\mathrm{CO}_{2}$, cuprite will react to form malachite. Cerussite $\left(\mathrm{PbCO}_{3}\right)$ and cassiterite $\left(\mathrm{SnO}_{2}\right)$ are the common corrosion products of lead and tin in bronze.

From Table 3 it can be seen that no lead corrosion products were identified on YLS1, consistent with the XRF data which indicate much lower levels of lead in the corrosion products on this sword than that of YLS2 and YLS3 (Table 2). Whether this is a reflection of the composition of the underlying alloy is difficult to be ascertain, but given that four samples were taken from YLS1 this appears highly likely. SEM-EDS examination of the metals showed that some swords in Lijiaba site are tinbronze (with $\mathrm{Pb}$ less than $2 \%$ ), while some are leaded tinbronze $[14,15]$. Lead corrosion products were found on both YLS2 and YLS3, and both pyromorphite and cerussite were detected on YLS2 and YLS3. Phosphatic corrosion products are present on all swords; libethenite on YLS1 and YLS3, and pyromorphite on YLS2 and YLS3 (Table 3).

According to Scott [2], who has reviewed the older literature, copper phosphates as corrosion products are not common. However, the reported copper phosphate corrosion products are libethenite $\left(\mathrm{Cu}_{2}(\mathrm{OH}) \mathrm{PO}_{4}\right)$, cornetite $\left(\mathrm{Cu}_{3}\left(\mathrm{PO}_{4}\right)(\mathrm{OH})_{3}\right)$, sampleite $\left(\mathrm{NaCaCu}_{5}\left(\mathrm{PO}_{4}\right)_{4}\right.$ $\mathrm{Cl} \cdot 5 \mathrm{H}_{2} \mathrm{O}$ ), hydrated copper phosphate (cupric orthophosphate $\left.\mathrm{Cu}_{3}\left(\mathrm{PO}_{4}\right)_{2} \cdot 3 \mathrm{H}_{2} \mathrm{O}\right)$ and zapatalite $\left(\mathrm{Cu}_{3} \mathrm{Al}_{4}\left(\mathrm{PO}_{4}\right)_{3}\right.$ $\left.(\mathrm{OH})_{9} \cdot 3 \mathrm{H}_{2} \mathrm{O}\right)$. Among these compounds the most frequent copper phosphate found as a corrosion product is libethenite $\left(\mathrm{Cu}_{2}(\mathrm{OH}) \mathrm{PO}_{4}\right)$ often associated with cremation sites. Recent work has reported both sampleite and libethenite on a Lydian bed of iron, bronze and copper dating to about $505 \mathrm{BC}$ [35], and libethenite was found by Berger on a Nordic bronze dagger from Schoolbek farm, Schleswig-Holstein, Germany, dating from the mid-2nd millennium BC [36]. Three bronze arrowheads unearthed at Dachengdun site in Anhui province, China all showed libethenite $\left(\mathrm{Cu}_{2}(\mathrm{OH}) \mathrm{PO}_{4}\right)$ in the corrosion products [37] while corrosion on a pair of bronze tweezers wrapped with silk products and buried near a person's waist in Gansu province, China was found to contain cupric orthophosphate $\left(\mathrm{Cu}_{3}\left(\mathrm{PO}_{4}\right)_{2} \cdot 3 \mathrm{H}_{2} \mathrm{O}\right)$ [38]. It appears that more frequent analysis of corrosion products on ancient bronzes is revealing more copper phosphates and the present study is in accordance with these findings. According to Mattson [39] and Fabrizi [40], bronzes with copper phosphate corrosion products are rare and less commonly found with copper chloride products which form in an acid environment. The analysis results of the three swords in this paper is in line with their conclusion. The two $\mathrm{pH}$ values obtained from Lijiaba site are close to neutral and slightly alkaline while soil from Birka where copper phosphate corrosion products also occur [39] shows a $\mathrm{pH}$ of about 8 . This is consistent with a $\mathrm{pH}$ control on the formation of phosphate corrosion products. Libethenite has been produced experimentally through the reaction $2 \mathrm{Cu}^{2+}+\mathrm{HPO}_{4}^{2-}+2 \mathrm{OH}^{-} \rightarrow \mathrm{Cu}_{2} \mathrm{PO}_{4} \mathrm{OH}+\mathrm{H}_{2} \mathrm{O}$ at $\mathrm{pH} 7$ [41]. Hence the presence of libethenite on the swords from Lijiaba may reflect the $\mathrm{pH}$ of the burial environment.

Pyromorphite $\left(\mathrm{Pb}_{5} \mathrm{Cl}\left(\mathrm{PO}_{4}\right)_{3}\right)$ as a corrosion product of bronze has been reported only in the last two decades $[8$, 42-49]. Angelini et al. described some of artifacts coming from the archaeological site of San Polo d'Enza (Italy) coated with a patina containing pyromorphite [42]. Zhang found pyromorphite in the patina of a bronze An (dining table) of the Han dynasty (175 BC) preserved in the Museum of Chenggu [43]. Pyromorphite was identified through XRD in some bronze Roman coins and artifacts found at Tharros (Sardinia, Italy) located along the coast of Sardinia [44], and the authors attributed the presence of phosphorus to the presence of large amounts of decomposing fragments of burnt bone. Mezzi found pyromorphite on bronze artifacts from Tharros (Western Sardinia, Italy) [8] and on $\mathrm{Cu}$-based archaeological artifacts from the Mediterranean basin through XRD analysis [45]. Mata and others found pyromorphite on coins from São Pedro, in Fronteira (Alentejo, Portugal) [46, 47]. Pyromorphite was also found in one bronze arrowhead from Dengzhou museum in Shandong province, China [48] and two bronze dagger-axes of Western Zhou dynasty unearthed in Baoji, Shaanxi province, China 
[49]. In addition, pyromorphite was found on lead beads unearthed in an Early Bronze Age cost cemetery at West Water Reservoir in south-east Scotland [50].

Research into the alloy compositions of Warring States swords from Lijiaba has not revealed the presence of phosphorus $[14,15]$. It therefore seems probable that the source of the phosphate ions in the corrosion products was in the burial environment.

A comparison of phosphate ion concentrations in soil samples from Lijiaba with those from another site in the Three Gorges region, Tuchengpo in Wushan county, and where copper phosphates were rarely detected, is shown in Fig. 7. The phosphate concentrations in soil samples from Lijiaba are significantly higher than those from Tuchengpo. This is consistent with the expectation that formation of libethenite, a relatively unusual corrosion product, would normally be dependent on the presence of elevated environmental levels of phosphate ions, assuming that there is no internal source in the bronze.

The formation of the phosphate compounds libethenite and pyromorphite is therefore related to phosphate in the environment. In fact, these three bronze swords were all buried in close association with buried individuals, specifically close to the human waist, as shown in Fig. 8 for YLS1. The excavation record indicates that no coffin was found in these three tombs and human bones were poorly preserved. Furthermore, the swords were excavated about $1.2-2.7 \mathrm{~m}$ below the ground surface, so the possibility that the phosphorus from fertilizer is low. The

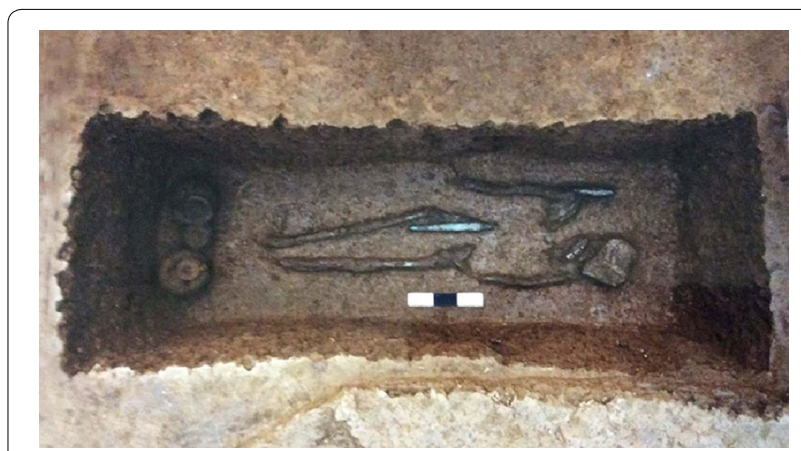

Fig. 8 Photo of tomb 00YLIIM82 in Lijiaba site, showing YLS1 (00YLIIM82:2) in the centre

phosphorus is therefore likely to have originated through the decomposition of human remains. The interaction of the damp burial environment due to the nearby the Pengxi river, the buried human bodies and the bronze promoted the formation of libethenite and pyromorphite.

It might be speculated that phosphatic minerals would tend to form on the swords where the highest concentration of phosphate ions was produced in the decomposition process. On YLS1, libethenite was detected in two samples which were located close to one another on the same side of the sword (YLS1-2 and YLS1-3, Fig. 1). This may indicate an area of the soil particularly enriched in phosphate but a much more extensive sampling regime would be needed to confirm this hypothesis.

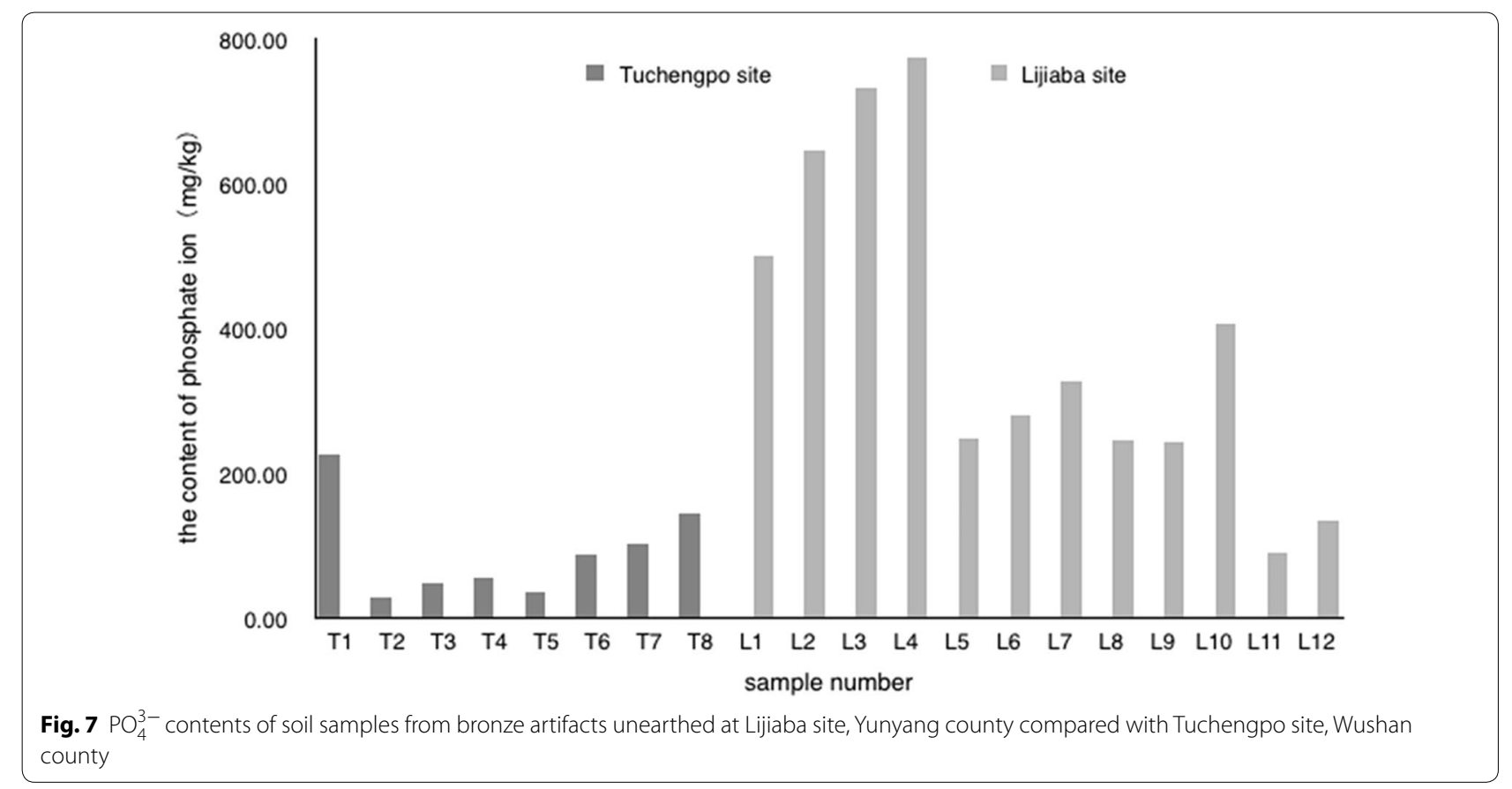




\section{Conclusion}

The micro-chemical structure of long-term corrosion products on bronze swords buried at Lijiaba site (southwest China) has been investigated by Raman and XRF spectroscopies.

The results show the presence of common corrosion products such as cuprite, malachite, cassiterite and cerussite but also the less common phosphatic corrosion products libethenite and pyromorphite. The occurrence of the phosphatic compounds may be attributed to the practice of including the swords in the burials at the waist, close to the position where they would have been worn during the lifetimes of the buried individuals. Decomposition of the bodies will have enriched the burial environment in phosphate, promoting the formation of phosphatic minerals. There are also tentative indications that the compounds formed reflect the detailed compositions of the underlying alloys but any relationship between the position of the analyzed area relative to the body and the production of phosphates cannot be confirmed from this particular dataset. Overall, however, this study emphasizes the importance of the micro-environment in determining the corrosion products which formed on early metals.

In order to obtain more information about the corrosion, we plan to investigate other bronze artifacts unearthed in this site and bronze swords unearthed in other sites and also to analyze the associated soil.

Finally, we point out that the gained knowledge is useful to select tailored conservation strategies to ensure the long life of these bronze swords and essential to monitor any long-term changes which may occur during storage.

\section{Authors' contributions \\ XF performed the analyses, carried out the interpretation of the results and drafted the manuscript. IF contributed to the interpretation of the data and drafted the manuscript. Both authors read and approved the final manuscript. \\ Author details \\ ${ }^{1}$ Chongqing China Three Gorges Museum, 236 Renmin Road, Chong- qing 400015, China. ${ }^{2}$ UCL Institute of Archaeology, 31-34 Gordon Square, London WC1H OPY, UK.}

\section{Acknowledgements}

We gratefully acknowledge Yunyang museum for supplying the samples.

\section{Competing interests}

The authors declare that they have no competing interests.

\section{Publisher's Note}

Springer Nature remains neutral with regard to jurisdictional claims in published maps and institutional affiliations.

Received: 28 July 2017 Accepted: 10 November 2017 Published online: 04 December 2017

\footnotetext{
References

1. Scott DA. Bronze disease: a review of some chemical problems and the role of relative humidity. J. Am. Inst. Conserv. 1990;29:193-206.
}

2. Scott DA. Copper and bronze in art: corrosion, colourants and conservation. Los Angeles: Getty Publications; 2002. p. 240-6.

3. Robbiola L, Blengino JM, Fiaud C. Morphology and mechanisms of formation of natural patinas on archaeological Cu-Sn alloys. Corros Sci. 1998;40(12):2083-111.

4. Oudbashi O, Hasanpour A, Davami P. Investigation on corrosion stratigraphy and morphology in some Iron Age bronze alloys vessels by OM, XRD and SEM-EDS methods. Appl Phys A. 2016;122:262.

5. De Ryck I, Adriaens A, Pantos E, Adams F. A comparison of microbeam techniques for the analysis of corroded ancient bronze objects. Analyst. 2003:128:1104-9.

6. Ingo GM, Angelini E, Bultrini G, Calliari I, Dabala M, De Caro T. Study of long-term corrosion layers grown on high-tin leaded bronzes by means of the combined use of GDOES and SEM + EDS. Surf Interface Anal. 2002;34:337-42.

7. Ingo GM, Riccucci C, Faraldi F, Casaletto MP, Guida G. Micro-chemical and micro-structural investigation of the corrosion products on "The Dancing Satyr"(Mazara del Vallo, Sicily, Italy). Appl Phys A. 2010;100:785-92.

8. Mezzi A, Angelini E, Riccucci C, Grassini S, De Caro T, Faraldi F, Bernardinic P. Micro-structural and micro-chemical composition of bronze artefacts from Tharros (Western Sardinia, Italy). Surf Interface Anal. 2012;44:958-62.

9. Riccucci $C$, Ingo GM, Faustoferri A, Pierigè MI, Parisi El, Carlo GD, Caro TD, Faraldi F. Micro-chemical and metallurgical study of Samnite bronze belts from ancient Abruzzo (central Italy, VIII-IV BC). Appl Phys A. 2013;113:959-70.

10. Sandu I, Ursulescu N, Sandu IG, Boungru O, Sandu ICA, Alexandru A. Pedological stratification effect of corrosion and contamination products on Byzantine bronze artefacts. Corros Eng Sci Technol. 2008;43:256-66.

11. Quaranta M, Sandu I. Micro-stratigraphy of copper-based archaeological objects: description of degradation mechanisms by means of an integrated approach. In: Proceedings of Ninth International Conference on NDT of Art, Jerusalem, Israel, 2008.

12. Cultural Relics Heritage Bureau of Chongqing, Resettlement Bureau of Chongqing. Collections of reports on the archaeological excavation in the Three Gorges Dam, Chongqing in 1997. Beijing: Sciences Press; 2001. p. 209-88 (in Chinese).

13. Cultural Relics Heritage Bureau of Chongqing, Resettlement Bureau of Chongqing. Collections of reports on the archaeological excavation in the Three Gorges Dam, Chongqing in 1998. Beijing: Sciences Press; 2003. p. 299-388 (in Chinese)

14. Yao Z. A technical study of bronze from the Ba-Shu region in the 5-2 century B.C.E and a discussion on the surficial craft of weapon. Beijing: Sciences Press; 2006 (in Chinese)

15. Yang X. A technicial study of bronze from Three Gorges region between Eastern Zhou to Han Dynasty. Beijing: Sciences Press; 2013 (in Chinese).

16. Schoukens I, Tourwe E, Guillaume J, Viet N, Vereeckena J, Terryna H. Study of corrosion products on Vietnamese archaeological bronzes dating from the Dong Son period. Surf. Interface Anal. 2008;40:474-7.

17. Ospitali F, Chiavari C, Martini C, Bernardi E, Passarinic F, Robbiolad L. The characterization of $\mathrm{Sn}$-based corrosion products in ancient bronzes: a Raman approach. J Raman Spectrosc. 2012;43:1596-603.

18. Piccardo P, Mödlinger M, Ghiara G, Campodonico S, Bongiorno V. Investigation on a "tentacle-like" corrosion feature on bronze age tin-bronze objects. Appl Phys A. 2013;113:1039-47.

19. Bertolotti G, Bersani D, Lottici PP, Alesiani M, Malcherek T, Schlüte J. MicroRaman study of copper hydroxychlorides and other corrosion products of bronze samples mimicking archaeological coins. Anal Bioanal Chem. 2012;402:1451-7

20. Wang $H$, Shi G, Tian M, Zhang L, Chen Y, Yang F, Cao X. Aerosol optical properties and chemical composition apportionment in Sichuan Basin, China. Sci Total Environ. 2017;577:245-57.

21. Yu B, Fang J, Huang E. Characteristics of the Raman spectra of archaeological malachites. J Raman Spectrosc. 2013;44:630-6.

22. Ivanda M, Waasmaier D, Endriss A, Ihringer J, Kirfel A, Kiefer W. Lowtemperature anomalies of cuprite observed by Raman spectroscopy and X-ray powder diffraction. J. Raman Spectrosc. 1997;28:487-93.

23. Bouchard M, Smith DC. Catalogue of 45 reference Raman spectra of minerals concerning research in art history or archaeology, especially on corroded metals and coloured glass. Spectrochimica Acta Part A. 2003:59:2247-66. 
24. Frost RL, Williams PA, Martens W, Kloprogge JT, Leverett P. Raman spectroscopy of the basic copper phosphate minerals cornetite, libethenite, pseudomalachite, reichenbachite and ludjibaite. J Raman Spectrosc. 2002;33:260-3.

25. Kharbish S, Andráš P, Luptáková J, Milovská S. Raman spectra of oriented and non-oriented Cu hydroxy-phosphate minerals: libethenite, cornetite, pseudomalachite, reichenbachite and ludjibaite. Spectrochim Acta Part Mol Biomol Spectrosc. 2014;130:152-63.

26. Frost RL. An infrared and Raman spectroscopic study of natural zinc phosphates. Spectrochimica Acta Part A. 2004;60:1439-45.

27. Reddy NCG, Reddy RR, Reddy GS, Reddy SL, Reddy BJ. EPR, optical absorption, MIR and Raman spectral studies on libethenite mineral. Cryst Res Technol. 2006;41(4):400-4.

28. Martens W, Frost RL. An infrared spectroscopic study of the basic copper phosphate minerals: cornetite, libethenite, and pseudomalachite. Am Miner. 2003;88:37-46.

29. Zhao X, Fan X, Wen $X$, Zhao Z. The protection and restoration of bronze artifacts unearthed at Lijiaba site, Yunyang county in the eighth symposium of China association for preservation technology of cultural relics. Beijing: Sciences Press; 2015. p. 1-7 (in Chinese)

30. Colomban P, Milande V, Bihan LL. On-site Raman analysis of Iznik pottery glazes and pigments. J Raman Spectrosc. 2004;35:527-35

31. Bernardi E, Chiavari C, Lenza B, Martini C, Morselli L, Ospitali F, Robbiola L. The atmospheric corrosion of quaternary bronzes: the leaching action of acid rain. Corro Sci. 2009;51:159-70.

32. Frost RL, Palmer S. A Raman spectroscopic study of the phosphate mineral pyromorphite $\mathrm{Pb}_{5}\left(\mathrm{PO}_{4}\right)_{3} \mathrm{Cl}$. Polyhedron. 2007;26:4533-41.

33. Bajda T, Mozgawa W, Manecki M, Flis J. Vibrational spectroscopic study of mimetite-pyromorphite solid solutions. Polyhedron. 2011;30:2479-85.

34. Giera A, Manecki M, Bajda T, Rakovan J, KwaśniakKominek M, Marchlewski T. Arsenate substitution in lead hydroxyl apatites: a Raman spectroscopic study. Spectrochim Acta Part A. 2016;152:370-7.

35. Scott DA, Maish JP. A lydian bed of iron, bronze and copper. Stud Conserv. 2010;55:3-19.

36. Berger D, Berthold C, Bunnefeld JH, Keuper M. A mysterious black ornamentation on an early bronze age dagger from Schoolbek (Kosel), Schleswig-Holstein, Germany. J Archaeol Sci. 2016;5:407-21.

37. Huang Y, Zhang J, Huang Y, Lu J, Mao Z. The analysis of bronze arrowheads dated to the Western Zhou period unearthed in Dachengdun, Hanshan county. Kaogu. 1991;2:1134-7 (in Chinese)
38. Ma YR. The corrosion products of bronzes and buried environment. In the 11 th National symposium on archaeology and conservation chemistry. Beijing: Relics Press; 2010. p. 105-7 (in Chinese).

39. Mattsson E, Nord AG, Tronner K, Fjaestad M, Lagerlof A, Ullen I, Brog GH. Deterioration of archaeological material in soil results on bronze artefacts. Stockholm: Print Gotab; 1996.

40. Fabrizi M, Ganiaris H, Tarling S, Scott DA. The occurrence of sampleite, a complex copper phosphate, as a corrosion product on copper alloy objects from Memphis, Egypt. Stud Conserv. 1989;34:45-51.

41. Ginion KE, Yoder CH. Preparation and analysis of libethenite. J Chem Educ. 2004;81:394.

42. Angelini $E$, Bianco $P$, Zucchi F. Proceedings of progress in the understanding and prevention of corrosion. vol. 1. Barcelona: 1993.

43. Zhang X. An unusual corrosion product pyromorphite, from a bronze an: a technical note. Stud Conserv. 2002;47(1):76-9.

44. Ingo GM, Decaro T, Riccucci C, Khosroff S. Uncommon corrosion phenomena of archaeological bronze alloys. Appl Phys A. 2006;83:581-8.

45. Mezzi A, de Caro T, Riccucci C, Faraldi F, Veroli C, Caschera D. Unusual surface degradation products grown on archaeological bronze artefacts. Appl Phys A. 2013;113:1121-8.

46. Mata AL, Carneiro A, Neto MMM, Proença LA, Salta MML, Mendonça MH, Fonseca ITE. Characterisation of five coins from the archaeological heritage of Portugal. J Solid State Electrochem. 2010;14:495-503.

47. Mata AL, Salta MML, Neto MMM, Mendonc MH, Fonseca ITE. Characterization of two Roman coins from an archaeological site in Portugal. Mater Corros. 2010;61:205-9.

48. Li T. Shandong Penglai Chutu Gudai Qingtongqi De Fushi Yanjiu (The corrosion study of ancient bronzes excavated from Penglai, Shandong Province). Master thesis. Hefei: University of Science and Technology of China; 2007 (in Chinese)

49. Yang Q, Qi Y, Fan B. FTIR analysis of corrosion products of bronze antiques. J Kunming Univ Sci Technol. 2006;31:80-2 (in Chinese).

50. Davis $M$, Hunter F, Livingstone $A$. The corrosion, conservation and analysis of a lead and cannel coal necklace from the Early Bronze Age. Stud Conserv. 1995:40(4):257-64.

\section{Submit your manuscript to a SpringerOpen ${ }^{\odot}$ journal and benefit from:}

- Convenient online submission

- Rigorous peer review

- Open access: articles freely available online

- High visibility within the field

Retaining the copyright to your article

Submit your next manuscript at $\boldsymbol{\nabla}$ springeropen.com 